\title{
Short-Term Frequency-Dependent Plasticity at Recurrent Mossy Fiber Synapses of the Epileptic Brain
}

\author{
Li Feng, Peter Molnár, and J. Victor Nadler \\ Departments of Pharmacology and Cancer Biology and Neurobiology, Duke University Medical Center, Durham, North Carolina 27710
}

\begin{abstract}
The recurrent mossy fiber pathway of the dentate gyrus expands dramatically in human temporal lobe epilepsy and in animal models of this disorder, creating monosynaptic connections among granule cells. This novel granule cell network can support reverberating excitation but is difficult to activate with low-frequency stimulation. This study used hippocampal slices from pilocarpine-treated rats to explore the dependence of synaptic transmission in this pathway on stimulus frequency. Minimal electrically evoked EPSCs exhibited a high failure rate $(\sim 60 \%)$. Stimulus trains delivered at a frequency of $<1 \mathrm{~Hz}$ depressed synaptic transmission, as evidenced by an increase in response failures. Conversely, stimulus trains delivered at higher frequencies reduced the percentage of response failures and increased the amplitude of compound EPSCs, including pharmacologically isolated NMDA receptor-mediated EPSCs. Short-term frequency-dependent facilitation was of modest size compared with mossy fiber synapses on other neuronal types. Facilitation depended on the activation of kainate receptors by released glutamate and was inhibited by feedback activation of type II metabotropic glutamate receptors. These results suggest that the recurrent mossy fiber pathway may be functionally silent during baseline asynchronous granule cell activity in vivo attributable, in part, to progressive transmission failure. The pathway may synchronize granule cell firing and may promote seizure propagation most effectively during the brief periods of high-frequency granule cell firing that occur during normal behavior, during the periods of hypersynchronous fast activity characteristic of epileptic brain and, most importantly, during the period of increasing granule cell activity that precedes a spontaneous seizure.
\end{abstract}

Key words: epilepsy; frequency-dependent facilitation; hippocampus; kainate receptor; mossy fiber; short-term plasticity; type II metabotropic glutamate receptor

\section{Introduction}

Changes in the dentate gyrus are believed to be important for the pathogenesis of temporal lobe epilepsy. Cell loss in the dentate hilus is the most commonly observed neuropathologic finding in persons with this disorder (Margerison and Corsellis, 1966). Furthermore, dentate granule cells have been shown to resist the propagation of seizures from the entorhinal cortex to the hippocampus (Collins et al., 1983; Stringer et al., 1989; Lothman et al., 1992). Monosynaptic connections among principal neurons serve as the anatomic substrate for synchronized discharge in area CA3 of the hippocampus, an unusually excitable region of the limbic system (Miles et al., 1984). Conversely, the paucity of such connections among dentate granule cells probably explains, in part, their resistance to such discharge. In many persons with temporal lobe epilepsy (Represa et al., 1989b; Sutula et al., 1989; Babb et al., 1991; Franck et al., 1995) and particularly in the pilocarpine model of temporal lobe epilepsy (Mello et al., 1993; Okazaki et al., 1995; Dashtipour et al., 2000, 2002; Ribak et al., 2000; Buckmaster et al., 2002), however, dentate granule cells form an interconnected synaptic network. This recurrent mossy fiber pathway mediates reverberating excitation that can reduce the threshold for granule cell synchronization (Tauck and Na-

Received Jan. 14, 2003; revised March 26, 2003; accepted April 9, 2003.

This work was supported by National Institutes of Health Grant NS 38108. We thank Y. Jiao for technical assistance.

Correspondence should be addressed to J. Victor Nadler, Department of Pharmacology and Cancer Biology, Box 3813, Duke University Medical Center, Durham, NC 27710. E-mail: nadle002@acpub.duke.edu.

P. Molnár's present address: Department of Bioengineering, Clemson University, Clemson, SC 29634-0905. Copyright @ 2003 Society for Neuroscience $\quad$ 0270-6474/03/235381-10\$15.00/0 dler, 1985; Cronin et al., 1992; Masukawa et al., 1992; Patrylo and Dudek, 1998; Hardison et al., 2000; Okazaki and Nadler, 2001), presumably facilitating participation of the dentate gyrus in seizures.

Despite formation of this novel recurrent circuitry, it remains difficult to evoke population bursting of dentate granule cells. Low-frequency stimulation of the perforant path in vivo (Buckmaster and Dudek, 1997) or of mossy fibers in the hippocampal slice (Tauck and Nadler, 1985; Cronin et al., 1992; Patrylo and Dudek, 1998; Hardison et al., 2000) usually does not evoke reverberating excitation, even when histological data reveal robust mossy fiber growth. Previous studies documented the roles of GABA inhibition and external $\left[\mathrm{K}^{+}\right]\left(\left[\mathrm{K}^{+}\right]_{\mathrm{o}}\right)$ in regulating epileptiform activity supported by the new granule cell network (Patrylo and Dudek, 1998; Hardison et al., 2000). Indeed, modest elevation of $\left[\mathrm{K}^{+}\right]_{\mathrm{o}}$ (by 1.25 or $2.5 \mathrm{~mm}$ ) reduces the amount of mossy fiber growth required to synchronize granule cell discharge (Hardison et al., 2000). Even in the presence of elevated $\left[\mathrm{K}^{+}\right]_{\mathrm{o}}$ and bicuculline, however, mossy fiber stimulation at a low frequency $(0.033 \mathrm{~Hz})$ failed to evoke a population burst in many slices. This resistance to recurrent activation may be related, in part, to the unreliability of transmission at mossy fiber $\rightarrow$ granule cell synapses. A previous study found that minimal photostimulation at a frequency of 1 per $15 \mathrm{sec}$ evoked a synaptic response in only $\sim 30 \%$ of the trials (Molnár and Nadler, 1999). Usedependent forms of synaptic plasticity may then regulate the ability of mossy fiber $\rightarrow$ granule cell synapses to support reverberating excitation. Mossy fiber synapses on CA3 pyramidal cells exhibit marked short-term frequency-dependent facilitation 
(Salin et al., 1996; Toth et al., 2000) over a range of presynaptic activity that corresponds to the normal firing frequencies of dentate granule cells in vivo (Jung and McNaughton, 1993). If mossy fiber $\rightarrow$ granule cell synapses exhibit such plasticity, they would then be expected to support synchronous granule cell discharge most effectively when driven at particular frequencies. Frequency-dependent plasticity at mossy fiber synapses depends on the identity of the postsynaptic cell; mossy fiber synapses on inhibitory interneurons exhibit either less facilitation than mossy fiber $\rightarrow$ pyramidal cell synapses or frequency-dependent depression (Toth et al., 2000; Doherty and Dingledine, 2001). This study explored short-term frequency-dependent plasticity at mossy fiber $\rightarrow$ granule cell synapses of the epileptic brain, with special emphasis on the roles of glutamate autoreceptors.

\section{Materials and Methods}

Pilocarpine-induced status epilepticus. Adult male Sprague Dawley rats (175-200 gm; Zivic Laboratories, Pittsburgh, PA) were injected intraperitoneally with pilocarpine hydrochloride $(350-380 \mathrm{mg} / \mathrm{kg}) 30 \mathrm{~min}$ after pretreatment with scopolamine methyl bromide and terbutaline hemisulfate (both $2 \mathrm{mg} / \mathrm{kg}$, i.p.). Status epilepticus, defined as a continuous limbic motor seizure of stage 2 or higher (Racine, 1972), was terminated $3.5 \mathrm{hr}$ after onset with sodium phenobarbital $(50 \mathrm{mg} / \mathrm{kg}$, i.p.). Although animals in the present study were not monitored systematically after recovery from status epilepticus, previous studies demonstrated that all rats that develop status epilepticus exhibit spontaneous limbic motor seizures after a 1-3 wk latent period (Mello et al., 1993; Lemos and Cavalheiro, 1996). Some pilocarpine-treated rats developed only brief seizures that never progressed to status epilepticus. Histological tests revealed no evidence of neuronal degeneration or supragranular mossy fiber growth in these animals (Okazaki et al., 1999). They were therefore used as controls. All protocols were approved in advance by the Duke University Institutional Animal Care and Use Committee.

Slice preparation and recording. Unless indicated otherwise, experiments used only rats that had developed status epilepticus after the administration of pilocarpine. Transverse $400-\mu \mathrm{m}$-thick slices were prepared from the caudal hippocampus with a vibratome $10-20$ weeks after pilocarpine administration. Slices were incubated in a beaker of high$\mathrm{Mg}^{2+}$ artificial CSF, which contained (in $\mathrm{mM}$ ): $122 \mathrm{NaCl}, 25 \mathrm{NaHCO}_{3}$, $3.1 \mathrm{KCl}, 1.8 \mathrm{CaCl}_{2}, 12 \mathrm{MgSO}_{4}, 0.4 \mathrm{KH}_{2} \mathrm{PO}_{4}$, and 10 D-glucose, $\mathrm{pH}$ 7.4. The medium was gassed continuously at room temperature with $95 \% \mathrm{O}_{2}$ and $5 \% \mathrm{CO}_{2}$. Beginning $45 \mathrm{~min}$ later, individual slices were transferred to a small experimental chamber, barely submerged in standard artificial CSF (1.2 $\mathrm{mm} \mathrm{MgSO}_{4}$ ), and superfused (3-4 $\mathrm{ml} / \mathrm{min}$ ) at room temperature.

Whole-cell patch-clamp recordings were obtained from dentate granule cells by the "blind" approach (Blanton et al., 1989). Patch electrodes were pulled from borosilicate glass $(1.5 \mathrm{~mm}$ outer diameter, $1.1 \mathrm{~mm}$ inner diameter; Sutter Instruments, Novato, CA) and had a tip resistance of $6-7.5 \mathrm{M} \Omega$. The tip of the electrode was filled by vacuum with a solution that contained (in $\mathrm{mM}$ ): 140 cesium gluconate, 15 HEPES, 3.1 $\mathrm{MgCl}_{2}, 1 \mathrm{CaCl}_{2}$, and 11 EGTA, pH 7.2, 276 mOsm. The electrode was then backfilled with an internal solution that contained $120 \mathrm{~mm}$ cesium gluconate, 10 mм HEPES, 2 mм Mg-ATP, 1 mм EGTA, 5 mм creatine phosphate, $10 \mathrm{~mm} n$-ethyl lidocaine chloride (QX-314), and $20 \mathrm{U} / \mathrm{ml}$ creatine phosphokinase, $\mathrm{pH} 7.4,276 \mathrm{mOsm}$. Whole-cell access was achieved in current-clamp mode; only cells with membrane voltage of greater than $-70 \mathrm{mV}$ on break-in (after correction for a $10 \mathrm{mV}$ liquid junction potential) were accepted for study.

Whole-cell patch-clamp recordings were made with an Axon Instruments (Foster City, CA) Axopatch 200B amplifier beginning $\sim 20 \mathrm{~min}$ after achieving whole-cell access. Series resistances were between 5 and 9 $\mathrm{M} \Omega$ and were compensated $75 \%$. Recordings were rejected if the series resistance changed by $>20 \%$. Signals were filtered at $2 \mathrm{kHz}$, digitized at $10 \mathrm{kHz}$, and stored for analysis offline with PClamp8 (Axon Instruments). At the end of the experiment, each slice was processed for Timm histochemistry to confirm the presence of recurrent mossy fiber growth.
Compound recurrent mossy fiber EPSC. Recordings were made from granule cells at the location in the cell body layer where the antidromic population spike was of greatest amplitude (Okazaki et al., 1999). The holding potential was $-80 \mathrm{mV}$. Mossy fibers were stimulated with a monopolar insulated $25-\mu \mathrm{m}$-diameter nichrome wire placed in stratum lucidum of area CA3b $100 \mu \mathrm{m}$ from the opening of the dentate hilus. A train of 10 near-maximal rectangular pulses (100 $\mu$ sec duration) was delivered at frequencies of $0.2-10 \mathrm{~Hz}$. Each train was repeated 10 times at $20-25 \mathrm{sec}$ intervals, and corresponding responses were averaged. All measurements were made from these averaged responses. A 20 sec intertrain interval proved sufficient for any short-term synaptic plasticity to decay completely. At least two stimulus frequencies were tested in each recording session. The superfusion medium contained $30 \mu \mathrm{M}$ bicuculline to block $\mathrm{GABA}_{\mathrm{A}}$ receptors. $\mathrm{GABA}_{\mathrm{B}}$ receptor-mediated currents were blocked by the use of a cesium-based internal solution that contained QX-314 but not GTP.

Compound EPSP. Recordings were made in current-clamp mode. The internal solution contained potassium gluconate instead of cesium gluconate, and QX-314 was omitted. Stimulus trains were delivered at frequencies of $0.2,2$, and $10 \mathrm{~Hz}$, and each train was repeated five times. Otherwise, these experiments were performed as described for the compound EPSC.

NMDA receptor-mediated EPSC. Stimulation and recording were performed as described for the compound EPSC with the following differences. To avoid overlap between successive responses, the range of stimulus frequencies was limited to $0.2-2 \mathrm{~Hz}$. The superfusion medium contained $30 \mu \mathrm{M}$ bicuculline and $10 \mu \mathrm{M}$ 2,3-dihydroxy-6-nitro-7sulfamyl-benzo(F) quinoxaline (NBQX), which blocks both AMPA and kainate receptors, $30 \mu \mathrm{M}$ 1-(4-aminophenyl)-3-methylcarbamyl-4methyl-7,8-methylenedioxy-3,4-dihydro-5H-2,3-benzodiazepine (GYKI 53655), which blocks AMPA receptors selectively, or $40 \mu \mathrm{M}$ (土)-4-(4-aminophenyl)-1,2-dihydro-1-methyl-2-propylcarbamoyl6,7-methylenedioxyphthalazine (SYM 2206), which also blocks AMPA receptors selectively. The holding potential was $-20 \mathrm{mV}$.

Minimal EPSC. Recordings were made from granule cells located at the apex of the cell body layer or in the suprapyramidal blade. The stimulating electrode was placed in the granule cell body layer $80-100 \mu \mathrm{m}$ from the recorded cell. The stimulus current was reduced until single pulses presented at a frequency of $0.2 \mathrm{~Hz}$ sometimes failed to evoke a synaptic response in the recorded cell. Responses were accepted as minimal EPSCs if their peak amplitude exceeded twice the baseline noise and they appeared at a constant latency of $\leq 5 \mathrm{msec}$. A train of 50 pulses was presented at frequencies of $0.2-10 \mathrm{~Hz}$. At least two stimulus frequencies were tested in each recording session. The change from one frequency to another took 1-2 min, which was enough time for any short-term plasticity to decay completely. The superfusion medium contained $30 \mu \mathrm{m}$ bicuculline, and the holding potential was $-80 \mathrm{mV}$.

To analyze properties of minimal EPSCs, traces without a minimal EPSC were averaged, and the resultant trace was subtracted electronically from the average of all traces with a minimal EPSC. Latency to onset, peak amplitude, $10-90 \%$ rise time, decay time constant, and charge transfer were determined with the use of MiniAnalysis (Synaptosoft, Decatur, GA). Rarely, a spontaneous event overlapped a portion of the evoked response. In those instances, measurements were restricted to the parameters that were uncontaminated.

Chemicals. D-Gluconic acid lactone, cesium hydroxide $(99.9 \% ; 50 \%$ by weight), HEPES, EGTA, creatine phosphate, creatine phosphokinase, sodium phenobarbital, pilocarpine hydrochloride, (-)scopolamine methyl bromide, and terbutaline hemisulfate were purchased from Sigma (St. Louis, MO); D-AP-5, (2S,2'R,3'R)-2-(2',3'-dicarboxycyclopropyl)glycine (DCG-IV), $(\alpha S)$ - $\alpha$-amino- $\alpha$-[(1S,2S)-2-carboxycyclopropyl]-9H-xanthine9-propanoic acid (LY 341495), and SYM 2206 were from Tocris Cookson (Bristol, UK); bicuculline methiodide was from Research Biochemicals (Natick, MA); and QX-314 was from Alomone Laboratories (Jerusalem, Israel). NBQX and GYKI 53655 were gifts from Novo Nordisk (Måløv, Denmark) and Eli Lilly (Indianapolis, IN), respectively. 

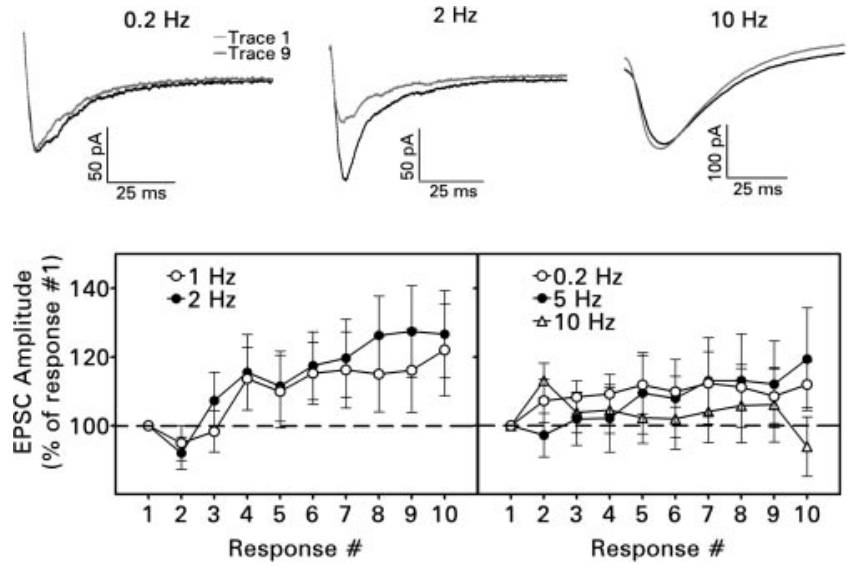

Figure 1. Frequency-dependent short-term facilitation of the compound recurrent mossy fiber EPSC during a train of 10 near-maximal electrical stimuli. Each train was presented 10 times, and corresponding responses were averaged. Recordings were made in the presence of $30 \mu \mathrm{m}$ bicuculline at a holding potential of $-80 \mathrm{mV}$. Top, Representative averaged traces illustrating facilitation during stimulation at $2 \mathrm{~Hz}$ but not at 0.2 or $10 \mathrm{~Hz}$. Bottom, Mean values \pm SEM for 11-17 cells. Only stimulus trains delivered at 1 or $2 \mathrm{~Hz}$ facilitated synaptic transmission significantly ( $p<0.005$ for $1 \mathrm{~Hz} ; p<0.001$ for $2 \mathrm{~Hz}$ by one-way repeated measures ANOVA; for the other frequencies, $p>0.4$ ).
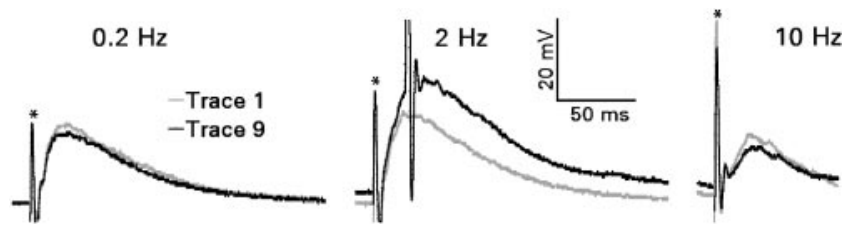

Figure 2. Frequency-dependent short-term facilitation of the compound recurrent mossy fiber EPSP during a train of 10 near-maximal electrical stimuli. Recordings were made in the presence of $30 \mu \mathrm{m}$ bicuculline. Representative single traces illustrate facilitation during stimulation at $2 \mathrm{~Hz}$ but not at 0.2 or $10 \mathrm{~Hz}$. In this example, the fourth and each succeeding stimulus in the $2 \mathrm{~Hz}$ train drove the firing of an action potential (shown truncated). Resting membrane potentials were $-75 \mathrm{mV}(0.2 \mathrm{~Hz}),-75 \mathrm{mV}(2 \mathrm{~Hz})$, and $-72 \mathrm{mV}(10 \mathrm{~Hz})$. Similar results were obtained in recordings from six granule cells. * Stimulus artifacts.

\section{Results}

Compound recurrent mossy fiber EPSC and EPSP

Whole-cell patch-clamp recordings were made from dentate granule cells in hippocampal slices prepared from rats that had developed status epilepticus after administration of pilocarpine. Stimulation of the mossy fibers in the presence of bicuculline evoked a short-latency ( $\leq 5 \mathrm{msec}$ ) inward current (Fig. 1, top) that was sometimes followed by delayed inward currents (Okazaki et al., 1999). These responses were abolished by glutamate receptor antagonists and thus were considered monosynaptic and polysynaptic EPSCs, respectively. Amplitude measurements were obtained only from the short-latency component. Compound EPSC amplitudes ranged from 21 to $283 \mathrm{pA}$ (median, 62 pA).

EPSC amplitude increased significantly during a 10-pulse train delivered at frequencies of 1 and $2 \mathrm{~Hz}$ (Fig. 1, bottom). However, the degree of facilitation was quite modest: an average of $22 \%$ at $1 \mathrm{~Hz}$ and $27 \%$ at $2 \mathrm{~Hz}$ for the 10 th response in the train. Stimulation at 5 or $10 \mathrm{~Hz}$ produced no significant frequencydependent plasticity under these conditions.

Stimulation at a frequency of $2 \mathrm{~Hz}$ also enhanced the amplitude and duration of the recurrent mossy fiber EPSP (Fig. 2). Stimuli that evoked a subthresold response initially could evoke one or two action potentials by the fourth stimulus in the train.

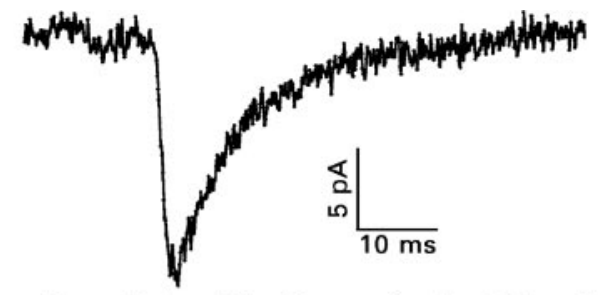

Properties of electrically-evoked minimal EPSCs

Peak amplitude (pA)
Latency (ms)
$10-90 \%$ rise time (ms)
Decay time constant (ms)
Charge transfer $(\mathrm{pC})$

Figure 3. Electrically evoked minimal recurrent mossy fiber EPSC. Top, Representative trace showing an average of the 15 responses recorded during a train of 50 minimal electrical stimuli delivered at a frequency of $0.2 \mathrm{~Hz}$. In this example, the peak amplitude was $15 \mathrm{pA}$; the $10-90 \%$ rise time was $3.4 \mathrm{msec}$; the decay time constant was $40.5 \mathrm{msec}$; and charge transfer was $167 \mathrm{pC}$. Bottom, Means \pm SEM for 40 granule cells.

The degree of facilitation appeared comparable with facilitation of the EPSC. Stimulation at 0.2 or $10 \mathrm{~Hz}$ produced no consistent changes in the response.

These results should be relevant to synaptic function during strong activation of the recurrent mossy fiber pathway. However, the compound mossy fiber EPSC proved less than ideal as an indicator of frequency-dependent plasticity, because (1) the response usually included polysynaptic components that might have influenced the amplitude measurement; (2) responses sometimes overlapped during trains delivered at a frequency of $10 \mathrm{~Hz}$ (7 of 13 recordings) because of the presence of either a single prolonged response or delayed inward currents; and (3) the monosynaptic response was somewhat asynchronous because of the small number of synapses activated. Reducing the stimulus current did not reliably isolate monosynaptic from polysynaptic responses. In fact, stimulus reduction was as likely to eliminate the monosynaptic component. Therefore, subsequent studies used responses that are likely to be purely monosynaptic: the EPSC evoked by minimal electrical stimulation and the NMDA receptor-mediated component of the compound EPSC.

\section{Minimal recurrent mossy fiber EPSC}

The intent of minimal electrical stimulation was to activate only one or a few mossy fiber synapses on the recorded cell. With use of our procedures, minimal electrically evoked EPSCs (Fig. 3, top) were recorded in 58 of 77 granule cells (75\%) from pilocarpine-treated rats that had developed status epilepticus and showed histochemical evidence of recurrent mossy fiber growth. In contrast, no minimal EPSCs were recorded in 19 granule cells from four control rats. Properties of these responses are summarized in Figure 3, bottom. Blockade of AMPA and kainate receptors with $10 \mu \mathrm{M}$ NBQX abolished minimal EPSCs.

The minimal electrically evoked EPSCs recorded in granule cells exhibited much slower response kinetics than those reported in most previous studies of mossy fiber synapses (Jonas et al., 1993; Toth et al., 2000; Doherty and Dingledine, 2001). However, the mean $10-90 \%$ rise time and decay time constant corresponded closely to values reported by Cossart et al. (2002) for minimal electrically evoked EPSCs at mossy fiber $\rightarrow$ pyramidal 


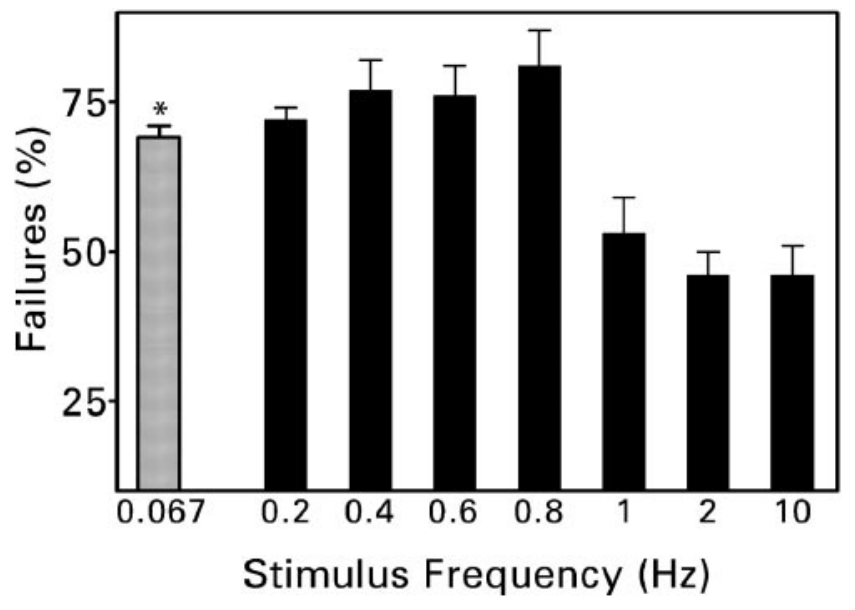

Figure 4. Percentage of response failures during a train of 50 minimal electrical stimuli. Recordings were made in the presence of $30 \mu \mathrm{m}$ bicuculline at a holding potential of $-80 \mathrm{mV}$. Values are means \pm SEM for $11(0.4-0.8 \mathrm{~Hz}), 20(1 \mathrm{~Hz}), 27(10 \mathrm{~Hz})$, or $39(0.2$ and $2 \mathrm{~Hz})$ cells. Stimulation at $1-10 \mathrm{~Hz}$ reduced the percentage of failures compared with each of the lower frequencies ( $p<0.01$ by Newman-Keuls test after one-way ANOVA yielded $p<0.001$ ). Although the failure rate tended to be lower during 2 and $10 \mathrm{~Hz}$ trains, the mean difference from $1 \mathrm{~Hz}$ trains was not statistically significant $(p>0.2)$. * Result obtained with minimal laser photostimulation (Molnár and Nadler, 1999).

cell synapses. The latter responses were shown to be mediated by both AMPA and kainate receptors, with the participation of kainate receptors accounting for the slow decay. Preliminary data suggest that kainate receptors also contribute significantly to most minimal recurrent mossy fiber EPSCs (L. Feng and J. V. Nadler, unpublished observations). Thus kainate receptor activation may primarily explain the slow mean response kinetics, although the presence of some mossy fiber synapses on the distal portion of the granule cell dendrite (Okazaki et al., 1995) suggests that dendritic filtering may also play a role in some instances.

During a train of 50 minimal electrical stimuli presented at frequencies of $0.2-0.8 \mathrm{~Hz}$, the failure rate was $\sim 70-75 \%$ (Fig. 4). This value compares closely with the percentage of failures observed previously with minimal photostimuli presented at a frequency of $0.067 \mathrm{~Hz}$ (Molnár and Nadler, 1999). Failures were observed significantly less often when the stimulus frequency was raised to $1 \mathrm{~Hz}$, the percentage apparently reaching a minimum $(46 \%)$ at $2 \mathrm{~Hz}$. The percentage of failures was approximately equal for the first 10 stimuli presented regardless of frequency ( $\sim 60 \%$; Fig. 5$)$. However, frequency-dependent changes in the failure rates were evident by the 20th stimulus. Repeated stimulation at a low frequency progressively increased the percentage of failures. For example, during a train of 50 pulses delivered at a frequency of $0.2 \mathrm{~Hz}$, the failure rate increased from an average of $61 \%$ for the first 10 stimuli in the train to $78 \%$ for the last 10 stimuli (Fig. 5B). This short-term depression disappeared when the stimulus frequency was raised to $1 \mathrm{~Hz}$. When stimulus trains were presented at a frequency of 2 or $10 \mathrm{~Hz}$, the failure rate declined significantly during the train. Between the first and last 10 stimuli, the failure rate declined by $36 \%$ at a frequency of $2 \mathrm{~Hz}$ and by $41 \%$ at a frequency of $10 \mathrm{~Hz}$. Thus frequency-dependent depression converted to facilitation over the narrow range of 0.8 to $2 \mathrm{~Hz}$.

Mossy fibers that contact CA3 pyramidal cells, CA3 interneurons, and dentate gyrus interneurons express type II metabotropic glutamate receptors (Shigemoto et al., 1997), activation of which inhibits glutamate release (Kamiya et al., 1996; Scanziani et al., 1997; Doherty and Dingledine, 1998; Toth et al., 2000). Our
A

Responses

$1-10$

Responses

41-50
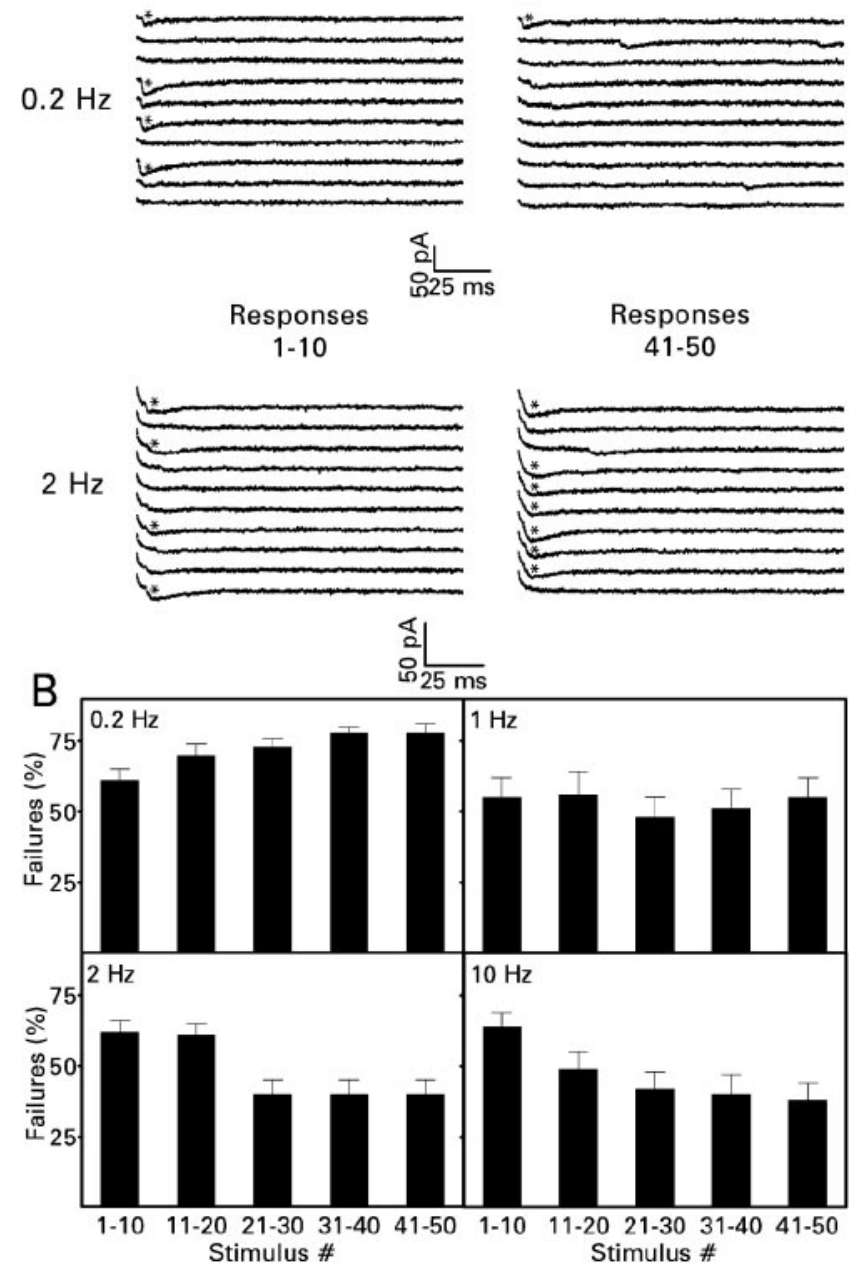

Figure 5. Short-term synaptic plasticity developed progressively during a train of 50 minimal electrical stimuli. $A$, Traces from representative experiments. In these examples, only 4 of the first 10 stimuli presented at a frequency of 0.2 or $2 \mathrm{~Hz}$ evoked a minimal EPSC. In contrast, only 1 of the last 10 stimuli presented at a frequency of $0.2 \mathrm{~Hz}$ evoked a synaptic response compared with 7 of the last 10 stimuli presented at a frequency of $2 \mathrm{~Hz}$. B, Mean values \pm SEM for the number of cells given in Figure 4. From stimuli 21-30 onward, repeated stimulation at a frequency of $0.2 \mathrm{~Hz}$ significantly increased the percentage of response failures, and repeated stimulation at a frequency of 2 or $10 \mathrm{~Hz}$ significantly reduced the percentage of response failures ( $p<0.01$ compared with stimuli 1-10 by Dunnett's test after one-way repeated measures ANOVAs yielded $p<0.001$ ). For other details, see Figure 4 .

initial studies of these receptors at mossy fiber $\rightarrow$ granule cell synapses tested the ability of the selective agonist DCG-IV to reduce the NMDA receptor-mediated component of the recurrent mossy fiber EPSC. In six cells, $1 \mu \mathrm{M}$ DCG-IV reduced the peak amplitude of this response (Fig. $6 A$ ) by $28 \pm 8 \%$ (mean \pm SEM; $p<0.05$, paired $t$ test). Subsequent experiments examined the effect of DCG-IV on the minimal EPSC (which is mediated by AMPA and kainate receptors). In nine cells, $1 \mu \mathrm{M}$ DCG-IV significantly increased the percentage of failures during stimulation at frequencies of $0.2,2$, and $10 \mathrm{~Hz}$ (Fig. $6 \mathrm{~B}$ ). At the same time, DCG-IV prevented the reduction in failures normally produced by a $2 \mathrm{~Hz}$ stimulus train and at least delayed the reduction observed with a $10 \mathrm{~Hz}$ train (Fig. $6 \mathrm{C}$ ). These changes in failure rate were not accompanied by any reduction in peak amplitude of the minimal EPSC (control, $11 \pm 1 \mathrm{pA}$; DCG-IV, $14 \pm 2 \mathrm{pA}$; means \pm SEM), consistent with a presynaptic site of action. 


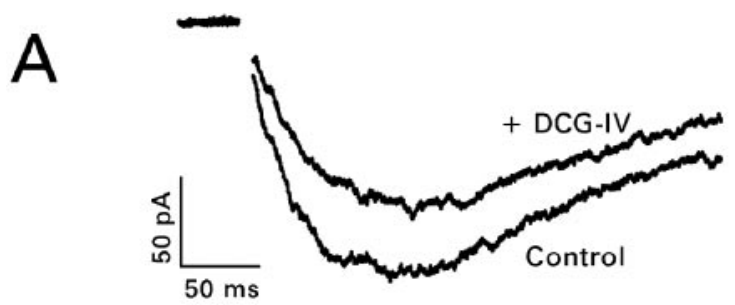

B

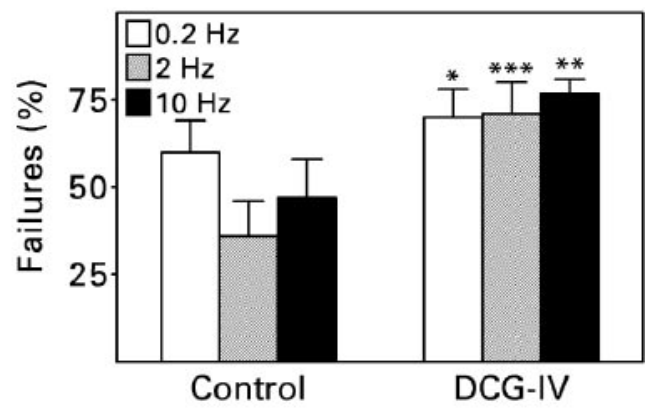

C

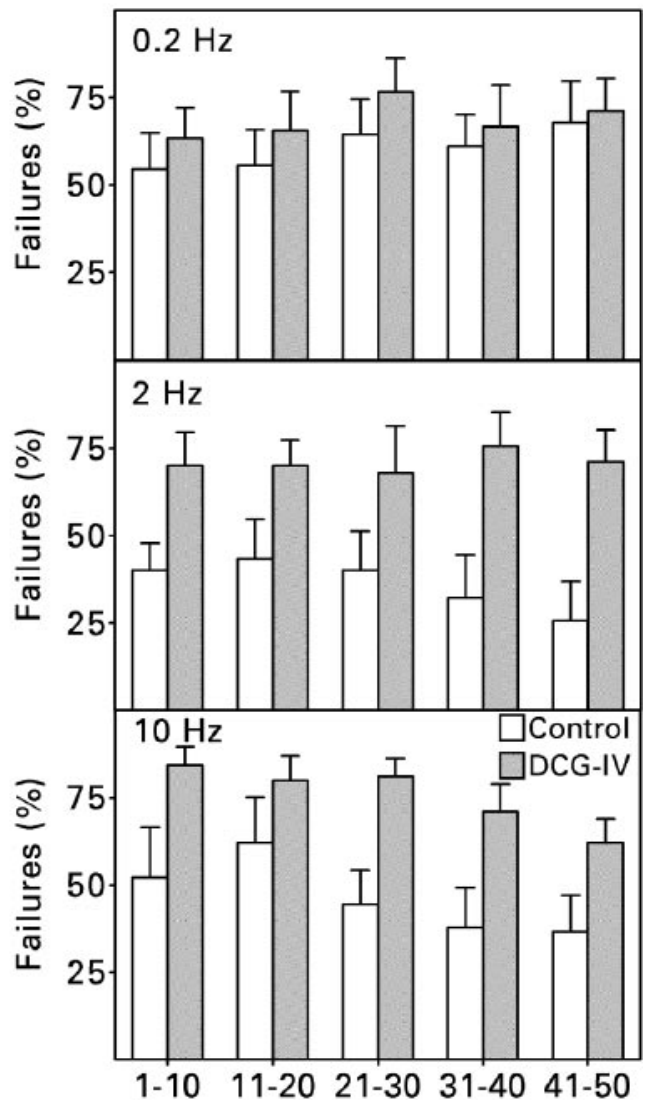

Figure 6. Activation of type II metabotropic glutamate receptors inhibited transmission at recurrent mossy fiber synapses. Recordings were made in the absence and then in the presence of bath-applied $1 \mu \mathrm{m}$ DCG-IV. A, The NMDA receptor-mediated EPSC was recorded in the presence of $10 \mu \mathrm{m} \mathrm{NBQX}$ and $30 \mu \mathrm{m}$ bicuculline at a holding potential of $-20 \mathrm{mV}$. These responses from a representative experiment are averages of six traces. Stimulus artifacts have been removed. DCG-IV reduced the size of the response. B, DCG-IV significantly increased the percentage of response failures during minimal electrical stimulation ( 50 stimuli) at frequencies of 0.2 , 2 , and $10 \mathrm{~Hz}$. Values are means \pm SEM for nine cells. ${ }^{*} p<0.05 ;{ }^{* *} p<0.001 ;{ }^{* *} p<0.02$ by paired $t$ test. $C$, Analysis of failure rates at different times during the stimulus train demonstrated that DCG-IV abolished the frequency-dependent facilitation normally observed during stimulation at $2 \mathrm{~Hz}$ and at least delayed the appearance of facilitation during stimulation at 10 $\mathrm{Hz}$. For other details, see Figure 4.
When used at a concentration of $100 \mathrm{nM}$, LY 341495 almost completely blocks the activation of type II metabotropic glutamate receptors, whereas it has much less effect, if any, on type I and III receptors (Schoepp et al., 1999). Bath application of 100 nM LY 341495 did not affect the failure rate of minimal recurrent mossy fiber EPSCs evoked at a frequency of $0.2 \mathrm{~Hz}$ but significantly reduced the percentage of failures obtained with 2 and 10 $\mathrm{Hz}$ stimulus trains (Fig. 7A). Its effect appeared to have developed fully within the first fifth of the train (Fig. 5B). LY 341495 did not change the peak amplitude of the response (control, $13 \pm 2 \mathrm{pA}$; LY $341495,14 \pm 3 \mathrm{pA}$; means \pm SEM; $n=9$ ). Thus the frequency-dependent reduction in transmission failures is limited by feedback of released glutamate onto presynaptic metabotropic glutamate receptors.

\section{NMDA receptor-mediated recurrent mossy fiber EPSC}

Frequency-dependent facilitation at mossy fiber $\rightarrow$ pyramidal cell synapses depends in large part on the activation of presynaptic kainate receptors by released glutamate (Schmitz et al., 2001). Kainate receptors are expressed normally in the supragranular zone of the dentate molecular layer (Monaghan and Cotman, 1982), and their density at that location increases in association with supragranular mossy fiber sprouting (Represa et al., 1989a). Thus it seemed reasonable that activation of presynaptic kainate receptors might account, at least in part, for frequencydependent facilitation at mossy fiber $\rightarrow$ granule cell synapses. The probable involvement of kainate receptors in the postsynaptic response complicates the use of minimal EPSCs to analyze the role of presynaptic kainate receptors. We therefore used the NMDA receptor-mediated component of the compound EPSC for this purpose. The NMDA component was isolated pharmacologically in two ways: by blocking both AMPA and kainate receptors with $10 \mu \mathrm{M}$ NBQX and by blocking AMPA receptors only with either $30 \mu \mathrm{M}$ GYKI 53655 (Paternain et al., 1995; Wilding and Huettner, 1995) or $40 \mu \mathrm{M}$ SYM 2206 (Pelletier et al., 1996; Li et al., 1999). Tests performed with the two AMPA receptorselective antagonists yielded indistinguishable results. NMDA receptor-mediated EPSC amplitudes ranged from 11 to $212 \mathrm{pA}$ (median, $27 \mathrm{pA}$ ).

Pilot studies on three cells confirmed the selectivity of the antagonists. In the presence of NBQX and bicuculline, $50 \mu \mathrm{M}$ D-AP-5 abolished all responses recorded at a holding potential of $-20 \mathrm{mV}$ (Fig. 8, top). Thus responses recorded under these conditions in the absence of D-AP-5 were mediated entirely by NMDA receptors. In the presence of SYM 2206 and bicuculline, a small response remained after the addition of D-AP-5 (Fig. 8, middle). Its latency to peak (14-23 msec after the stimulus) was shorter than that of the response recorded before the addition of D-AP-5 (33-36 msec after the stimulus), whereas its kinetics were more rapid (Fig. 8, bottom). These properties suggest that the D-AP-5-resistant component reflected activation of postsynaptic kainate receptors (Li et al., 1999; Cossart et al., 2002). It accounted for only $\sim 10 \%$ of the peak amplitude of the total response.

When the NMDA component was isolated under conditions that prevented the activation of kainate receptors (NBQX and bicuculline), repetitive stimulation at a frequency of 1 or $2 \mathrm{~Hz}$ depressed the response (Fig. 9). By the end of a 10-pulse train delivered at either frequency, the peak amplitude had declined by an average of $27 \%$. Unblocking kainate receptors (GYKI 53655 or SYM 2206 and bicuculline) converted frequency-dependent depression into facilitation. By the end of a 10-pulse train delivered at either 1 or $2 \mathrm{~Hz}$, the peak amplitude had increased by an aver- 


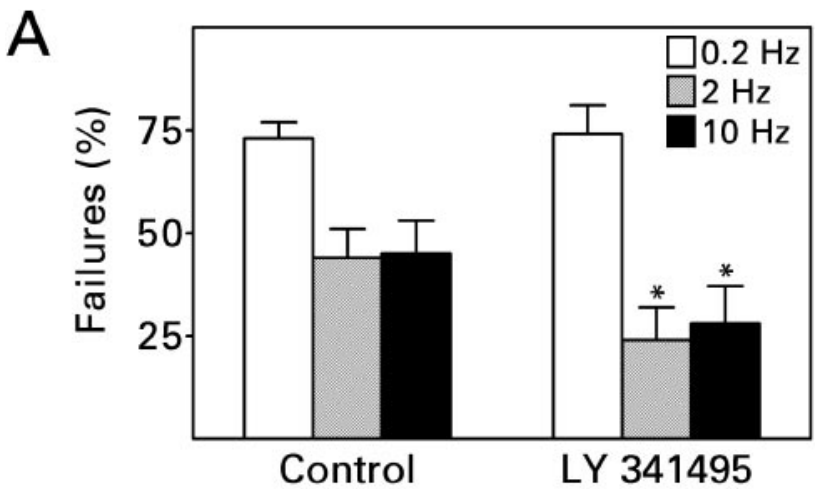

B

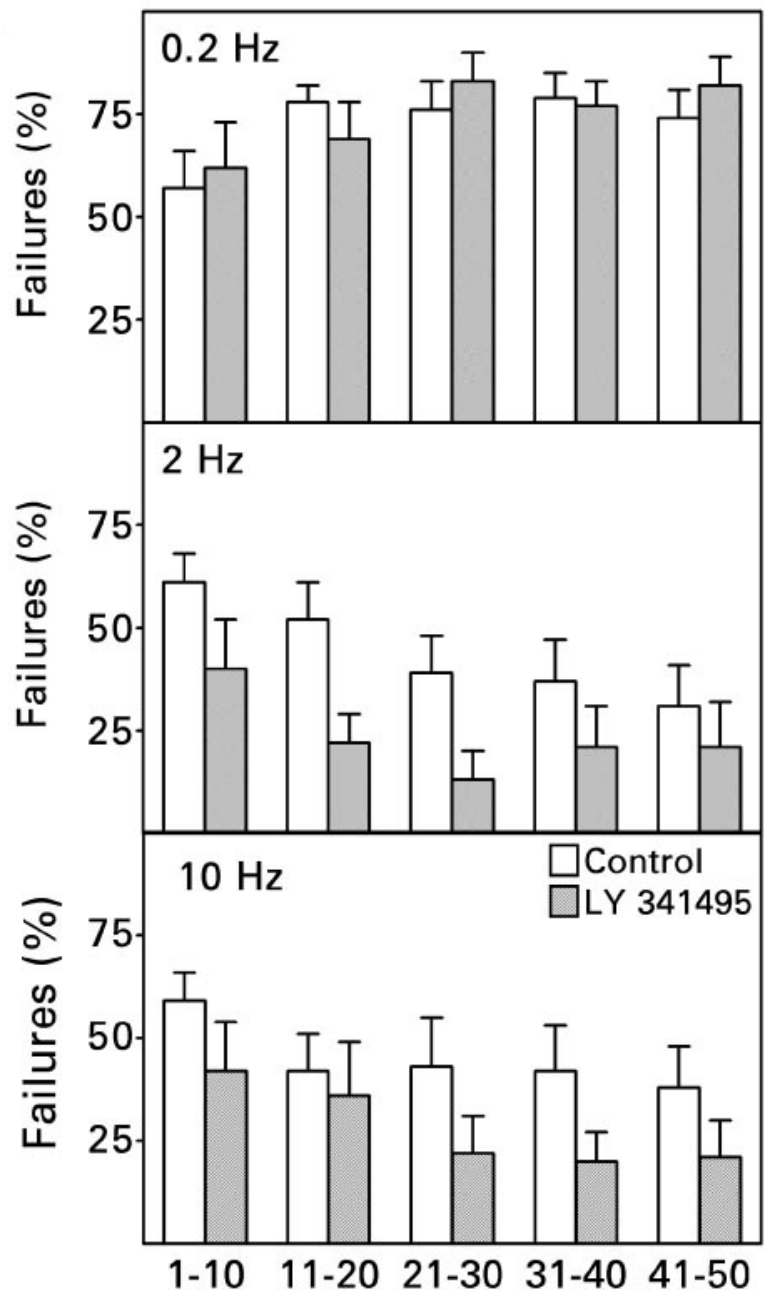

Figure 7. Block of type II metabotropic glutamate receptors enhanced the frequency-dependent reduction in response failures during minimal electrical stimulation. Recordings were made in the absence and then in the presence of bath-applied $100 \mathrm{~nm} \mathrm{LY} 341495$. A, LY 341495 did not affect the percentage of responsefailures during stimulation at a frequency of $0.2 \mathrm{~Hz}$ butreduced the percentage of failures during 2 and $10 \mathrm{~Hz}$ stimulus trains. Values are means \pm SEM for nine cells. ${ }^{*} p<0.05$ by paired $t$ test. $B$, Analysis of failure rates at different times during the stimulus train suggested no obvious time or use dependence in the action of $L Y$ 341495; its onset of action must have occurred within the first 10 stimuli. For other details, see Figure 4.

age of 25\%. The NMDA receptor- and kainate receptor-mediated components of the recurrent mossy fiber EPSC were differentiated in three experiments. The NMDA component grew by an average of $89 \%$ (range, 59-148\%) during a $2 \mathrm{~Hz}$ train, and the kainate component grew by an average of $48 \%$ (range, 22-72\%).

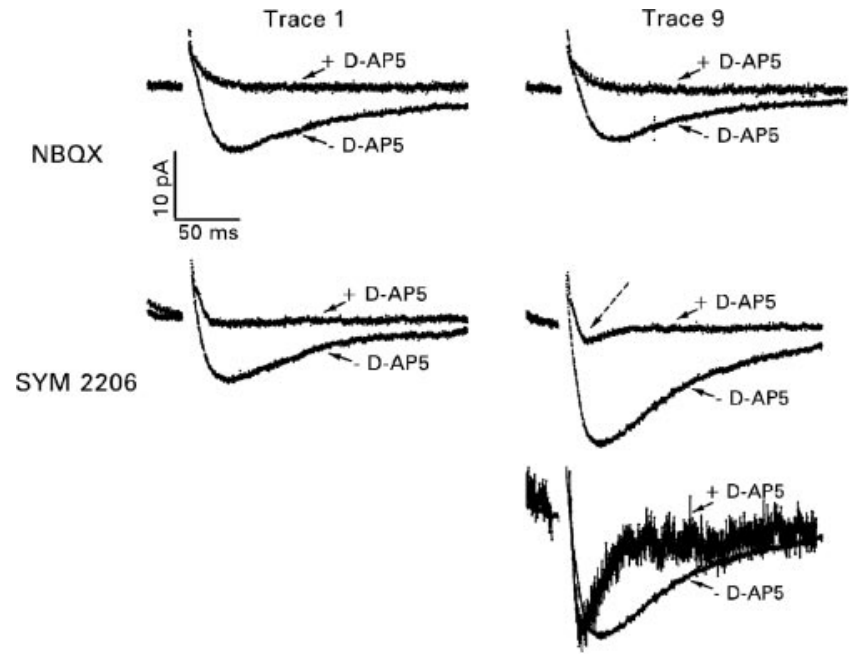

Figure 8. NMDA receptor-mediated recurrent mossy fiber EPSC isolated pharmacologically with $30 \mu \mathrm{m}$ bicuculline and either $10 \mu \mathrm{m}$ NBQX or $40 \mu \mathrm{m}$ SYM 2206. Recordings shown are from representative experiments in which a train of 10 near-maximal stimuli was presented at a frequency of $2 \mathrm{~Hz}$. The stimulus train was repeated 10 times, and corresponding traces were averaged. Then $50 \mu \mathrm{m} \mathrm{D-AP-5}$ was added to the superfusion medium, and the stimulation protocol was repeated. Stimulus artifacts have been removed. Top, During superfusion with NBQX, D-AP-5 abolished the response recorded at a holding potential of $-20 \mathrm{mV}$. Note the smaller response to the ninth stimulus in the train. Middle, During superfusion with SYM 2206, a small, presumably kainate receptor-mediated, response (dashed arrow) remained after addition of D-AP-5 to the superfusion medium. Note the larger response to the ninth stimulus in the train. Bottom, The kainate receptor-mediated component of the response to the ninth stimulus in the train (+D-AP-5) is scaled to the peak amplitude of the response recorded before addition of D-AP-5 to the superfusion medium. Note the change in the time course of the evoked response after application of D-AP-5.

Additional experiments explored the interaction between feedback activation of kainate and type II metabotropic glutamate receptors. LY 341495 reversed the frequency-dependent depression observed during $2 \mathrm{~Hz}$ stimulation with kainate receptors blocked (Fig. 10, top). Little effect was observed during the early part of the stimulus train, but response depression appeared to reverse completely by the seventh stimulus. Under conditions that allowed for kainate receptor activation, frequencydependent facilitation was observed in the presence or absence of LY 341495 (Fig. 10, bottom). Facilitation was usually observed with somewhat fewer stimuli when LY 341495 was present, but the ultimate magnitude of facilitation was unchanged. Thus the facilitatory effect of activating kainate receptors primarily occluded the effect of blocking type II metabotropic glutamate receptors. In the same experiments, LY 341495 did not affect responses evoked at a frequency of $0.2 \mathrm{~Hz}$ (data not shown).

\section{Discussion}

Our results suggest that mossy fiber synapses on dentate granule cells exhibit short-term plasticity distinctly different from that described for mossy fiber synapses on other neuronal types. Like mossy fiber synapses on dentate gyrus interneurons located at the border of the hilus (Doherty and Dingledine, 2001) and on some inhibitory CA3 interneurons (Toth et al., 2000), repetitive activation of mossy fiber $\rightarrow$ granule cell synapses can provoke shortterm depression. However, this type of plasticity occurs in the recurrent pathway only during activation at frequencies of $<1$ Hz. In contrast, mossy fiber $\rightarrow$ interneuron synapses exhibit short-term depression only when activated at higher frequencies. Like mossy fiber synapses on CA3 pyramidal cells (Salin et al., 1996; Toth et al., 2000) and on some inhibitory CA3 interneurons 
$0.2 \mathrm{~Hz}$

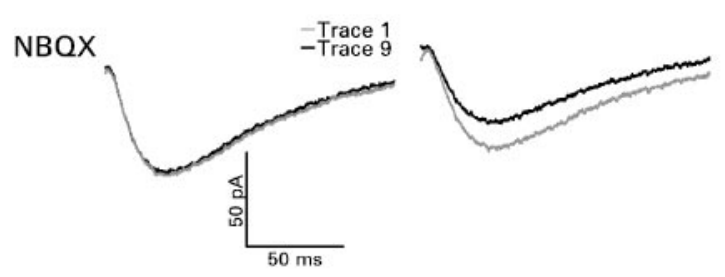

SYM 2206

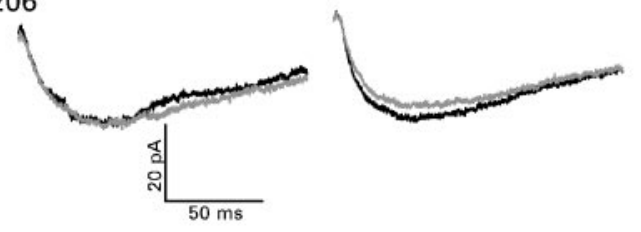
(NBOX)

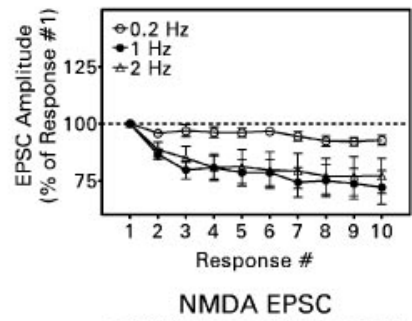

(GYKI 53655/SYM 2206)

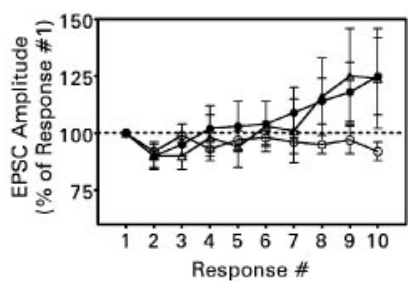

Figure 9. Unblocking kainate receptors converts short-term depression into facilitation. The NMDA receptor-mediated EPSC was isolated pharmacologically with $30 \mu \mathrm{m}$ bicuculline and $10 \mu \mathrm{M}$ NBQX, $30 \mu \mathrm{m}$ GYKI 53655, or $40 \mu \mathrm{m}$ SYM 2206. Left, Recordings from representative experiments performed as described in Figure 8, except that D-AP-5 was not used. In the presence of NBQX the amplitude of the response declined during the stimulus train, whereas response amplitude increased when SYM 2206 was used. Right, Mean values \pm SEM for 10 cells in each group. The synaptic response exhibited statistically significant depression when the mossy fibers were stimulated at a frequency of 1 or $2 \mathrm{~Hz}$ in the presence of NBQX ( $p<0.001$ in each case by one-way repeated measures ANOVA). In contrast, the response facilitated during stimulation at these same frequencies in the presence of GYKI 53655 or SYM 2206 ( $p<0.005$ for $1 \mathrm{~Hz} ; p<0.001$ for $2 \mathrm{~Hz}$ ).

(Toth et al., 2000), repetitive activation of mossy fiber $\rightarrow$ granule cell synapses can also provoke short-term facilitation. However, its magnitude and dynamic range are far smaller than at mossy fiber $\rightarrow$ pyramidal cell synapses. Although the dynamic range of recurrent mossy fiber synapses $(0.8-2 \mathrm{~Hz})$ approximates that of mossy fiber synapses on those inhibitory CA3 interneurons that exhibit short-term facilitation, the magnitude of facilitation is smaller. Thus short-term synaptic plasticity in the recurrent mossy fiber pathway combines elements of the frequencydependent depression and facilitation reported for other divisions of the mossy fiber projection, yielding a unique dependence of the postsynaptic response on presynaptic activity. There does not appear to be any clear morphological basis for these differences among mossy fiber synapses. On average, mossy fiber boutons that contact dentate granule cells are intermediate in diameter between those that contact CA3 pyramidal cells, on the one hand, and inhibitory interneurons, on the other (Okazaki et al., 1995; Molnár and Nadler, 1999).

\section{Short-term frequency-dependent depression}

Dentate granule cells in vivo fire action potentials at a low rate punctuated by brief periods of high-frequency discharge (Henze et al., 2002). For the rat, normal baseline activity during a learning task is in the range of $0.1-1 \mathrm{~Hz}$ (Jung and McNaughton, 1993). Our results suggest that repetitive granule cell firing at frequencies within this range leads to progressive transmission failure. During minimal electrical stimulation at a frequency of $0.2 \mathrm{~Hz}$, the already high percentage of failures increased by an average of $28 \%$ during a train of 50 stimuli. It is not clear whether the transmission rate had plateaued by the end of the train or whether it would have continued to decline with additional stimulation. Recurrent mossy fiber synapses may not synchronize granule cell discharge effectively under these conditions. In fact,
NMDA EPSC

during baseline asynchronous granule cell activity in vivo, the recurrent pathway may be functionally silent.

Electrophysiological studies of the recurrent mossy fiber pathway have typically used stimulus frequencies much lower than $1 \mathrm{~Hz}$. Under these conditions, minimal electrical stimulation usually evokes no postsynaptic response, and the transmission rate is likely to either remain the same during repeated stimulation or to decline. The use of low stimulus frequencies may explain, in part, the finding that mossy fiber stimulation usually evokes no synaptically driven granule cell population response, even when Timm histochemistry demonstrates robust sprouting into the dentate molecular layer (Tauck and Nadler, 1985; Cronin et al., 1992; Patrylo and Dudek, 1998; Hardison et al., 2000).

Short-term depression could still be observed at recurrent mossy fiber synapses during stimulation at frequencies of 1 or $2 \mathrm{~Hz}$, provided that kainate receptors were blocked. This process was mediated, after some delay, by feedback activation of type II metabotropic glutamate receptors. Because these receptors are localized mainly on the preterminal axon and on regions of the bouton outside the synaptic cleft (Shigemoto et al., 1997), the delay presumably reflected the time required for glutamate to overflow the synapse and to reach a concentration at the receptor sufficient for activation.

\section{Short-term frequency-dependent facilitation}

Facilitation was manifested as a reduction in response failures during minimal electrical stimulation $(\sim 40 \%)$, an increase in the amplitude of the compound EPSC $(\sim 25 \%)$, an increase in the amplitude and duration of the compound EPSP, and an increase in the amplitude of the NMDA receptor-mediated EPSC $(\sim 25 \%)$. Although the magnitude of facilitation is rather small compared with that observed at mossy fiber synapses on other neuronal populations, it appears comparable with that reported for Schaffer collateral $\rightarrow$ commissural synapses in area CA3 (Salin et al., 1996). Furthermore, the transmission rate of minimal EPSCs at the end of a 50-pulse train delivered at a frequency of 2 or $10 \mathrm{~Hz}$ was approximately twice that at the end of a train delivered at a frequency of $0.2 \mathrm{~Hz}$. These effects are likely to be physiologically significant, because even a small enhancement of excitatory transmission could substantially increase synchronized granule cell activity supported by the recurrent mossy fiber pathway (Traub and Dingledine, 1990).

Short-term facilitation depends on the activation of kainate receptors by released glutamate, as previously described for mossy fiber $\rightarrow$ pyramidal cell synapses (Schmitz et al., 2001). In fact, kainate receptor activation appears to be an absolute requirement for stimulus trains to facilitate transmission at mossy fiber synapses on granule cells. Although kainate receptors are expressed on both the presynaptic and postsynaptic membranes at mossy fiber synapses, previous reports suggest that feedback onto presynaptic receptors is critical (Schmitz et al., 2001; Kamiya et al., 2002). Our finding that stimulus trains enhanced all 


\section{NMDA EPSC (NBQX \pm LY 341495)}

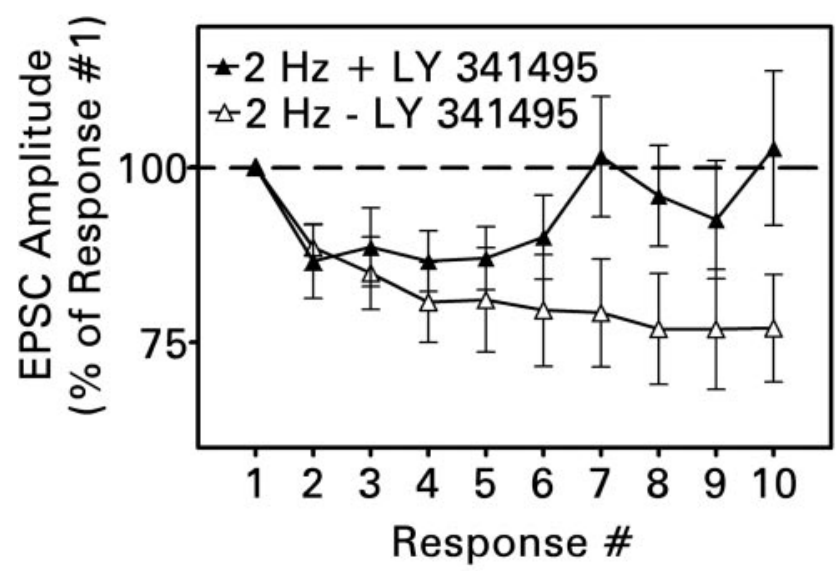

\section{NMDA EPSC (SYM $2206 \pm$ LY 341495)}

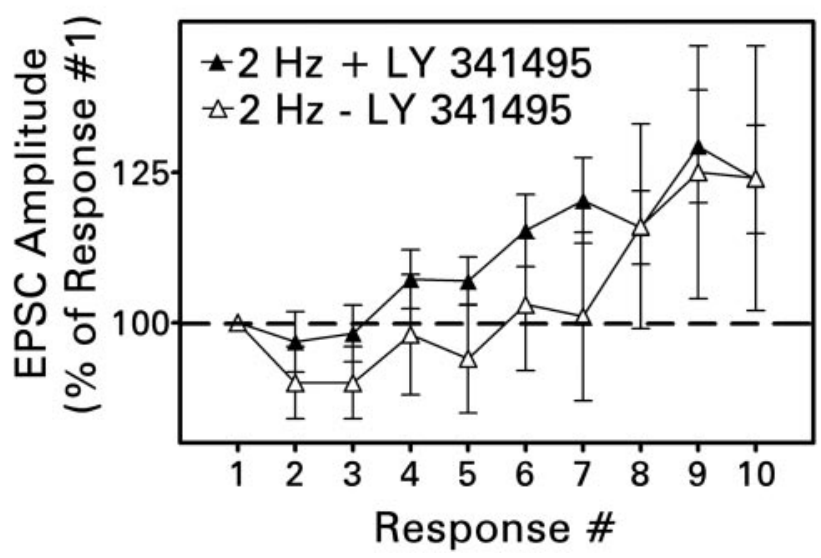

Figure 10. Block of type II metabotropic glutamate receptors modified short-term plasticity at recurrent mossy fiber synapses in response to a $2 \mathrm{~Hz}$ stimulus train. Values are means \pm SEM for 10 cells in each group. Top, LY $341495(100 \mathrm{~nm})$ reduced and eventually abolished response depression observed when the NMDA receptor-mediated EPSC was isolated with $30 \mu \mathrm{m}$ bicuculline and $10 \mu \mathrm{M}$ NBQX [ $p<0.001$ by Newman-Keuls test after two-way ANOVA (treatment $X$ stimulus number)]. Bottom, When the NMDA receptor-mediated component was isolated with $30 \mu \mathrm{m}$ bicuculline and $40 \mu \mathrm{m}$ SYM 2206, facilitation usually appeared earlier in the train during application of $L Y 341495$. However, this effect was not statistically significant $[p>$ 0.1 , two-way ANOVA (treatment $\times$ stimulus number)].

three components of the recurrent mossy fiber EPSC is consistent with this idea; certainly facilitation of the small kainate component of the postsynaptic response was insufficient to account for our results. Kainate receptors act in opposition to type II metabotropic glutamate receptors. Activation of metabotropic receptors limited the reduction in transmission failures produced by 2 and $10 \mathrm{~Hz}$ stimulus trains and tended to reduce the rate at which facilitation of the NMDA receptor-mediated EPSC developed. Kainate receptors, like type II metabotropic receptors, have been localized to the mossy fiber axon (Petralia et al., 1994). Under our experimental conditions, metabotropic receptors appeared to be activated earlier during a stimulus train than kainate receptors. However, kainate receptor activation had the greater effect on recurrent mossy fiber transmission. Activation of kainate receptors during near-maximal mossy fiber stimulation at a frequency of $2 \mathrm{~Hz}$ occluded any effect of blocking metabotropic receptors on the ultimate magnitude of short-term facilitation. The mechanism(s) underlying this interaction requires investigation. Kainate receptor activation produces mossy fiber afterdepolarization that enhances action potential-driven $\mathrm{Ca}^{2+}$ influx (Kamiya et al., 2002), whereas activation of type II metabotropic glutamate receptors both reduces presynaptic $\mathrm{Ca}^{2+}$ influx and downregulates the exocytotic machinery (Kamiya and Ozawa, 1999). Kainate receptor-driven $\mathrm{Ca}^{2+}$ entry may counteract one or both effects of metabotropic receptor activation.

Transmission at recurrent mossy fiber synapses also undergoes a process that might be called "reversal of facilitation," that is, the loss of short-term facilitation when the magnitude of the postsynaptic response is substantially increased. This process was most clearly evident with $10 \mathrm{~Hz}$ stimulus trains. During minimal electrical stimulation at $10 \mathrm{~Hz}$, the transmission rate increased substantially. However, the compound EPSC and EPSP failed to potentiate during stimulation of the pathway at $10 \mathrm{~Hz}$ with nearmaximal electrical pulses. Although this result may have been influenced in some experiments by overlap of successive responses, strong activation of the recurrent mossy fiber pathway in vivo probably evokes long-lasting polysynaptically driven EPSCs. Thus short-term facilitation might occur in vivo over just the same narrow range of frequencies $(1-2 \mathrm{~Hz}$ ) as in the hippocampal slice. Finally, stimulation of the pathway at a frequency of $10 \mathrm{~Hz}$ markedly reduces and can even abolish the synaptic response if the first stimulus in the train evokes granule cell epileptiform activity (Hardison et al., 2000). Thus $10 \mathrm{~Hz}$ activity potentiates weak recurrent mossy fiber responses and attenuates strong responses. The mechanism(s) that underlies reversal of facilitation remains to be determined.

\section{Implications for seizure propagation}

Frequency-dependent short-term plasticity joins GABA inhibition and $\left[\mathrm{K}^{+}\right]_{\mathrm{o}}$ as a key factor that regulates participation of the recurrent mossy fiber pathway in granule cell epileptiform activity. Frequency-dependent depression contributes to the failure of this pathway to synchronize granule cell discharge effectively during normal activity. Frequency-dependent facilitation may promote synchronized discharge when granule cell activity reaches $\geq 1 \mathrm{~Hz}$. Occasions when this might occur include the brief periods of high-frequency activity during normal behavior (Henze et al., 2002), the periods of hypersynchronous fast activity characteristic of epileptic brain (Bragin et al., 1999, 2002), and the period of increasing granule cell activity that precedes a spontaneous seizure (Bragin et al., 1999; Finnerty and Jefferys, 2000).

Each dentate granule cell innervates $\sim 14$ CA3 pyramidal cells and 40-50 inhibitory CA3 interneurons (Acsady et al., 1998). The ability of the dentate gyrus to filter epileptiform activity derives, in part, from mossy fiber-evoked feedforward inhibition that prevents the spread of excitation from the few targeted CA3 pyramidal cells to the rest of the synaptically interconnected pyramidal cell population. This inhibitory drive can be overcome either through intense activation of granule cells (Lothman et al., 1992) or through frequency-dependent facilitation in the mossy fiber pathway (Henze et al., 2002). Frequency-dependent facilitation is of greater magnitude and operates over a much broader dynamic range at mossy fiber synapses on pyramidal cells than on interneurons (Toth et al., 2000). Moreover, some mossy fiber synapses on CA3 interneurons undergo frequency-dependent depression. The overall effect is to enhance the driving of pyramidal cells relative to interneurons (Henze et al., 2002). Thus frequency-dependent facilitation in the recurrent mossy fiber 
pathway is expected to enhance synchronous population discharge of dentate granule cells directly and CA3 pyramidal cells indirectly. Other changes in the dentate gyrus of epileptic brain, such as depressed synaptic inhibition (Sloviter, 1991; Rice et al., 1996; Williamson et al., 1999; Doherty and Dingledine, 2001), would increase the impact of synaptic facilitation, leading to a potentially explosive gain of excitability. We propose that the recurrent mossy fiber pathway promotes seizure propagation from the entorhinal cortex to the hippocampus mainly when granule cells are driven at a frequency appropriate to promote synaptic facilitation.

\section{References}

Acsady L, Kamondi A, Sik A, Freund T, Buzsáki G (1998) GABAergic cells are the major postsynaptic targets of mossy fibers in the rat hippocampus. J Neurosci 18:3386-3403.

Babb TL, Kupfer WR, Pretorius JK, Crandall PH, Levesque MF (1991) Synaptic reorganization by mossy fibers in human epileptic fascia dentata. Neuroscience 42:351-363.

Blanton MG, Lo Turco J, Kriegstein AR (1989) Whole-cell recording from neurons in slices of reptilian and mammalian cortex. J Neurosci Methods 30:203-210.

Bragin A, Engel J, Wilson CL, Fried I, Mathern GW (1999) Hippocampal and entorhinal cortex high-frequency oscillations $(100-500 \mathrm{~Hz})$ in human epileptic brain and in kainic acid-treated rats with chronic seizures. Epilepsia 40:127-137.

Bragin A, Mody I, Wilson CL, Engel J (2002) Local generation of fast ripples in epileptic brain. J Neurosci 22:2012-2021.

Buckmaster PS, Dudek FE (1997) Network properties of the dentate gyrus in epileptic rats with hilar neuron loss and granule cell axon reorganization. J Neurophysiol 77:2685-2696.

Buckmaster PS, Zhang GF, Yamawaki R (2002) Axon sprouting in a model of temporal lobe epilepsy creates a predominantly excitatory feedback circuit. J Neurosci 22:6650-6658.

Collins RC, Tearse RG, Lothman EW (1983) Functional anatomy of limbic seizures: focal discharges from medial entorhinal cortex in rats. Brain Res 280:25-40.

Cossart R, Epsztein J, Tyzio R, Becq H, Hirsch J, Ben-Ari Y, Crepel V (2002) Quantal release of glutamate generates pure kainate and mixed AMPA/ kainate EPSCs in hippocampal neurons. Neuron 35:147-159.

Cronin J, Obenaus A, Houser CR, Dudek FE (1992) Electrophysiology of dentate granule cells after kainate-induced synaptic reorganization of the mossy fibers. Brain Res 573:305-310.

Dashtipour K, Tran PH, Okazaki MM, Nadler JV, Ribak CE (2000) Ultrastructural features of hilar ectopic granule cells in the rat dentate gyrus are different from those of granule cells in the granule cell layer. Brain Res 890:261-271.

Dashtipour K, Tran PH, Yan X-X, Okazaki MM, Nadler JV, Ribak CE (2002) Quantitative and morphological analysis of dentate granule cells with recurrent basal dendrites from normal and epileptic rats. Hippocampus 12:235-244.

Doherty J, Dingledine R (1998) Differential regulation of excitatory synaptic inputs to hilar border interneurons in the dentate gyrus by metabotropic glutamate receptors. J Neurophysiol 79:2903-2910.

Doherty J, Dingledine R (2001) Reduced excitatory drive onto interneurons in the dentate gyrus after status epilepticus. J Neurosci 21:2048-2057.

Finnerty GT, Jefferys JG (2000) 9-16 Hz oscillation precedes secondary generalization of seizures in the rat tetanus toxin model of epilepsy. J Neurophysiol 83:2217-2226.

Franck JE, Pokorny J, Kunkel DD, Schwartzkroin PA (1995) Physiologic and morphologic characteristics of granule cell circuitry in human epileptic hippocampus. Epilepsia 36:543-558.

Hardison JL, Okazaki MM, Nadler JV (2000) Modest increase in extracellular potassium unmasks effect of recurrent mossy fiber growth. J Neurophysiol 84:2380-2389.

Henze DA, Wittner L, Buzsáki G (2002) Single granule cells reliably discharge targets in the hippocampal CA3 network in vivo. Nat Neurosci 5:790-795.

Jonas P, Major G, Sakmann B (1993) Quantal components of unitary EPSCs at the mossy fibre synapse on CA3 pyramidal cells of rat hippocampus. J Physiol (Lond) 472:615-663.
Jung MW, McNaughton BL (1993) Spatial selectivity of unit activity in the hippocampal granular layer. Hippocampus 3:165-182.

Kamiya H, Ozawa S (1999) Dual mechanism for presynaptic modulation by axonal metabotropic glutamate receptor at the mouse mossy fibre-CA3 synapse. J Physiol (Lond) 518:497-506.

Kamiya H, Shinozaki H, Yamamoto C (1996) Activation of metabotropic glutamate receptor type $2 / 3$ suppresses transmission at rat hippocampal mossy fibre synapse. J Physiol (Lond) 493:447-455.

Kamiya H, Ozawa S, Manabe T (2002) Kainate receptor-dependent shortterm plasticity of presynaptic $\mathrm{Ca}^{2+}$ influx at the hippocampal mossy fiber synapses. J Neurosci 22:9237-9243.

Lemos T, Cavalheiro EA (1996) Status epilepticus and the late development of spontaneous seizures in the pilocarpine model of epilepsy. Epilepsy Res [Suppl] 12:137-144.

Li P, Wilding TJ, Kim SJ, Calejesan AA, Huettner JE, Zhuo M (1999) Kainate receptor-mediated sensory synaptic transmission in mammalian spinal cord. Nature 397:161-164.

Lothman EW, Stringer JL, Bertram EH (1992) The dentate gyrus as a control point for seizures in the hippocampus and beyond. Epilepsy Res [Suppl] 7:301-313.

Margerison JH, Corsellis JAN (1966) Epilepsy and the temporal lobes. Brain 89:499-530.

Masukawa LM, Uruno K, Sperling M, O’Connor MJ, Burdette LJ (1992) The functional relationship between antidromically evoked field responses of the dentate gyrus and mossy fiber reorganization in temporal lobe epileptic patients. Brain Res 579:119-127.

Mello LEAM, Cavalheiro EA, Tan AM, Kupfer WR, Pretorius JK, Babb TL, Finch DM (1993) Circuit mechanisms of seizures in the pilocarpine model of chronic epilepsy: cell loss and mossy fiber sprouting. Epilepsia 34:985-995.

Miles R, Wong RKS, Traub RD (1984) Synchronized afterdischarges in the hippocampus: contribution of local circuit interaction. Neuroscience 12:1016-1022.

Molnár P, Nadler JV (1999) Mossy fiber-granule cell synapses in the normal and epileptic rat dentate gyrus studied with minimal laser photostimulation. J Neurophysiol 82:1883-1894.

Monaghan DT, Cotman CW (1982) The distribution of $\left[{ }^{3} \mathrm{H}\right]$ kainic acid binding sites in rat CNS as determined by autoradiography. Brain Res 252:91-100.

Okazaki MM, Nadler JV (2001) Glutamate receptor involvement in dentate granule cell epileptiform activity evoked by mossy fiber stimulation. Brain Res 915:58-69.

Okazaki MM, Evenson DA, Nadler JV (1995) Hippocampal mossy fiber sprouting and synapse formation after status epilepticus in rats: visualization after retrograde transport of biocytin. J Comp Neurol 352:515-534.

Okazaki MM, Molnár P, Nadler JV (1999) Recurrent mossy fiber pathway in rat dentate gyrus: synaptic currents evoked in presence and absence of seizure-induced growth. J Neurophysiol 81:1645-1660.

Paternain AV, Morales M, Lerma J (1995) Selective antagonism of AMPA receptors unmasks kainate receptor-mediated responses in hippocampal neurons. Neuron 14:185-189.

Patrylo PR, Dudek FE (1998) Physiological unmasking of new glutamatergic pathways in the dentate gyrus of hippocampal slices from kainateinduced epileptic rats. J Neurophysiol 79:418-429.

Pelletier JC, Hesson DP, Jones KA, Costa A-M (1996) Substituted 1,2-dihydrophthalazines: potent, selective, and noncompetitive inhibitors of the AMPA receptor. J Med Chem 39:343-346.

Petralia RS, Wang YX, Wenthold RJ (1994) Histological and ultrastructural localization of the kainate receptor subunits, KA2 and GluR6/7, in the rat nervous system using selective antipeptide antibodies. J Comp Neurol 349:85-110.

Racine RJ (1972) Modification of seizure activity by electrical stimulation. II. Motor seizure. Electroencephalogr Clin Neurophysiol 32:281-284.

Represa A, Le Gal La Salle G, Ben-Ari Y (1989a) Hippocampal plasticity in the kindling model of epilepsy in rats. Neurosci Lett 99:345-350.

Represa A, Robain O, Tremblay E, Ben-Ari Y (1989b) Hippocampal plasticity in childhood epilepsy. Neurosci Lett 99:351-355.

Ribak CE, Tran PH, Spigelman I, Okazaki MM, Nadler JV (2000) Status epilepticus-induced hilar basal dendrites on rodent granule cells contribute to recurrent excitatory circuitry. J Comp Neurol 428:240-253.

Rice A, Rafiq A, Shapiro SM, Jakoi ER, Coulter DA, DeLorenzo RJ (1996) Long-lasting reduction of inhibitory function and gamma-aminobutyric 
acid type A receptor subunit mRNA expression in a model of temporal lobe epilepsy. Proc Natl Acad Sci USA 93:9665-9669.

Salin PA, Scanziani M, Malenka RC, Nicoll RA (1996) Distinct short-term plasticity at two excitatory synapses in the hippocampus. Proc Natl Acad Sci USA 93:13304-13309.

Scanziani M, Salin PA, Vogt KE, Malenka RC, Nicoll RA (1997) Usedependent increases in glutamate concentration activate presynaptic metabotropic glutamate receptors. Nature 385:630-634.

Schmitz D, Mellor J, Nicoll RA (2001) Presynaptic kainate receptor mediation of frequency facilitation at hippocampal mossy fiber synapses. Science 291:1972-1976.

Schoepp DD, Jane DE, Monn JA (1999) Pharmacological agents acting at subtypes of metabotropic glutamate receptors. Neuropharmacology 38:1431-1476.

Shigemoto R, Kinoshita A, Wada E, Nomura S, Ohishi H, Takada M, Flor PJ, Neki A, Abe T, Nakanishi S, Mizuno N (1997) Differential presynaptic localization of metabotropic glutamate receptor subtypes in the rat hippocampus. J Neurosci 17:7503-7522.

Sloviter RS (1991) Permanently altered hippocampal structure, excitability, and inhibition after experimental status epilepticus in the rat: the "dormant basket cell" hypothesis and its possible relevance to temporal lobe epilepsy. Hippocampus 1:41-66.
Stringer JL, Williamson JM, Lothman EW (1989) Induction of paroxysmal discharges in the dentate gyrus: frequency dependence and relationship to afterdischarge production. J Neurophysiol 62:126-135.

Sutula T, Cascino G, Cavazos J, Parada I, Ramirez L (1989) Mossy fiber synaptic reorganization in the epileptic human temporal lobe. Ann Neurol 26:321-330.

Tauck DL, Nadler JV (1985) Evidence of functional mossy fiber sprouting in the hippocampal formation of kainic acid-treated rats. J Neurosci 5:1016-1022.

Toth K, Suares G, Lawrence JJ, Philips-Tansey E, McBain CJ (2000) Differential mechanisms of transmission at three types of mossy fiber synapse. J Neurosci 20:8279-8289.

Traub RD, Dingledine R (1990) Model of synchronized epileptiform bursts induced by high potassium in CA3 region of rat hippocampal slice: role of spontaneous EPSPs in initiation. J Neurophysiol 64:1009-1018.

Wilding TJ, Huettner JE (1995) Differential antagonism of -amino-3hydroxy-5-methyl-4-isoxazolepropionic acid-preferring and kainatepreferring receptors by 2,3-benzodiazepines. Mol Pharmacol 47:582-587.

Williamson A, Patrylo PR, Spencer DD (1999) Decrease in inhibition in dentate granule cells from patients with medial temporal lobe epilepsy. Ann Neurol 45:92-99. 